\title{
TERAPI TAWA UNTUK MENURUNKAN KECENDERUNGAN BURNOUT PADA GURU PENDAMPING ANAK BERKEBUTUHAN KHUSUS
}

\author{
Risna Hayati, Rahma Widyana, Mutingatu Sholichah \\ IAIN Pontianak, J1. Letnan Jendral Soeprapto No 19 Pontianak, Kalimantan Barat \\ Nana_girlsmile4@yahoo.com
}

\begin{abstract}
The purpose of this study was to determine the effect of laughter therapy in reducing the tendency of burnout in special needs teacher assistant. Subject of this research is 10 people with medium burnout indication, and five people of experimental group and five people of controlled group. The instrument used to measure the tendency of burnout with burnout propensity scale based on the symptoms of burnout. The experimental design uses design experimental quasi of pre-test and post-test of control group. Interventions given to subject are laugther therapy to experimental group for 8 meetings for two weeks. The quantitative analysis uses non parametric test with Mann Whitney test on gain score pre-post of experimental groups and controlled groups, its results $Z$ value of $-2,009$ with significant level of $0,045(\mathrm{p}<0,05)$. The qualitative analysis is done by analyzing the result of interview and observation. The results show that there are significant differences in levels of burnout tendencies between the experimental group and the control group. The experimental group showed decrease of burnout indication while controlled group did not experience the decreasing.
\end{abstract}

Keywords: burnout, laughter therapy, tendency of burnout

\begin{abstract}
Abstrak
Tujuan penelitian ini adalah untuk mengetahui pengaruh terapi tawa dalam menurunkan kecenderungan burnout pada guru pendamping anak berkebutuhan khusus. Subjek dalam penelitian ini berjumlah 10 orang yang mengalami kecenderungan burnout. Instrumen yang digunakan untuk mengukur kecenderungan burnout dengan Skala Kecenderungan Burnout. Rancangan eksperimen menggunakan quasi eksperimen pre-test post-test control group design. Intervensi yang diberikan kepada subjek dalam kelompok eksperimen berupa terapi tawa sebanyak 8 kali pertemuan dalam dua minggu. Analisis kuantitatif menggunakan non parametric test dengan uji Mann Whitney pada gain score pre-post kelompok eksperimen dan kontrol, yang menghasilkan nilai $Z-2,009$ dengan taraf signifikansi $p=0,045(p<0,05)$. Analisis kualitatif dilakukan dengan menganalisis hasil wawancara, dan observasi. Hasil yang didapat memperlihatkan bahwa ada perbedaan yang sangat signifikan pada tingkat kecenderungan burnout antara kelompok eksperimen dan kelompok kontrol. Kelompok eksperimen mengalami penurunan kecenderungan burnout sedangkan kelompok kontrol tidak mengalami penurunan.
\end{abstract}

Kata kunci: burnout, kecenderungan burnout, terapi tawa. 


\section{Pendahuluan}

Pendidikan adalah hak seluruh warga negara tanpa membedakan asalusul, status sosial ekonomi, maupun keadaan fisik seseorang, termasuk anakanak yang mempunyai kelainan tercantum dalam UUD 1945 pasal 31. Isi UndangUndang Nomor 20 Tahun 2003 tentang Sistem Pendidikan Nasional, hak anak untuk memperoleh pendidikan dijamin penuh tanpa adanya diskriminasi termasuk anak-anak yang mempunyai kelainan atau anak yang berkebutuhan khusus. Menurut Alimin (2004) anak berkebutuhan khusus dapat diartikan sebagai seorang anak yang memerlukan pendidikan khusus yang disesuiakan dengan hambatan belajar dan kebutuhan masing-masing anak secara individual. Kondisi seperti ini memerlukan seorang pendidik yang mampu memberikan pelayanan khusus.

Anak berkebutuhan khusus diantaranya seperti ADHD, autis, sindrom down, retardasi mental, slow learner, dan global delay. Ciri-ciri anak berkebutuhan khusus secara umum mengalami gangguan pemusatan perhatian, hiperaktifitas, mengalami masalah interaksi sosial, komunikasi, perilaku yang terbatas dan berulang, dan mengalami gangguan emosi. Gangguan perkembangan membutuhkan pendampingan khusus dari guru yang berdampak beban kerja yang berat bagi guru.

Menurut Departemen Pendidikan Nasional, guru merupakan seorang individu yang berprofesi atau pekerjaannya sebagai pengajar. Sebagai seorang guru diharapkan sehat secara fisiologis maupun psikologis, agar mampu memberikan pembelajaran dan pelayanan yang baik pada anak didik. Menurut Daradjat (Rahman, 2007) seorang guru dituntut untuk selalu memiliki tingkah laku positif misalnya penyabar, penuh perhatian, bersikap hangat, humoris, dan yang paling penting memiliki rasa empati.

Guru tidak selalu dihadapkan pada kondisi yang positif. Guru pendamping anak berkebutuhan khusus yang berbeda jauh saat mendampingi anak normal pada umumnya, dalam pendampingan terkadang guru dihadapkan pada pengalaman negatif dengan siswa sehingga menimbulkan ketegangan emosional. Menurut Pamangsah (2008) setiap pekerjaan yang dilakukan oleh seseorang dapat memberikan beban tersendiri bagi pelakunya, seperti beban fisik, mental, maupun sosial. Menurut Carolina (2009) salah satu pekerjaan berprofesi sebagai guru mengkhususkan diri pada penanganan anak didik yang mengalami masalah baik fisik maupun mental, dalam melaksanakan tugasnya guru sangat rawan mengalami stres. Hal ini disebabkan karena interaksi secara langsung dengan pekerjaan atau lingkungan kerja yang sering kali tidak kondusif, seperti saat menghadapi perilaku anak berkebutuhan khusus yang sering kali berubah-ubah.

Sukmaningrum (2005) menjelaskan bahwa bekerja sebagai pelayanan kemanusiaan dapat mengalami dampak psikologis negatif akibat pekerjaan yang diembannya. Dampak psikologis yang sudah lama dikenal dalam dunia pekerjaan sebagai pendampingan adalah burnout. Demirel et al (2005) menjelaskan bahwa profesi yang bekerja di pelayanan kemanusiaan seperti guru, dokter, pekerja sosial dan perawat rentan terhadap burnout. Farber (Demirel et al, 2005) menyatakan bahwa 5-20\% guru Amerika menderita burnout.

Berdasarkan hasil wawancara awal dilakukan pada 5 guru pendamping anak berkebutuhan khusus Sekolah Dasar Khusus X di Yogyakarta, di depatakan bahwa beberapa guru yang mendampingi anak berkebutuhan khusus beresiko 
mengalami masalah stres. Hampir semua guru pendamping dipastikan pernah mendapatkan pengalaman negatif dari anak yang didampingi. Mendampingi anak berkebutuhan khusus cenderung mengalami kelelahan fisik, karena lebih banyak energi yang terkuras, adanya rasa jenuh, lelah secara emosional, dan terkadang adanya keinginan-keinginan dari orang tua yang sangat besar terhadap kemajuan anaknya dapat membuat beban bagi guru.

Burnout pada guru dapat terjadi karena beban pekerjaan yang berlebihan, konflik peran dan yang membuat lingkungan kelas yang kurang kondusif. Bekerja di bidang pelayanan kemanusiaan sebagai guru pendamping anak berkebutuhan khusus banyak membutuhkan dan menguras energi secara terus menerus, sehingga dapat menimbulkan kelahaman emosional.

Burnout dapat terjadi jika individu dihadapkan pada masalah stres yang terus menerus dan berlangsung lama, kondisi seperti ini akan membuat individu terkuras banyak energi, sehingga menyebabkan kelelahan. Individu yang mengalami stres akan memproduksi hormon stres, serta mengaktifkan sistem saraf simpatik, sehingga meningkatkan jumlah epinefrin dan norepinefrin yang dilepaskan dari medula adrenal. Menurut Freudenberger (2003) bahwa orang yang mengalami burnout biasanya mengalami kelelahan, mudah tersinggung, dan marah tanpa alasan yang jelas, keluhan psikosomatis, mudah curiga, disorientasi dan mengalami kebosanan. Berikut mekanisme fisiologis pada burnout:

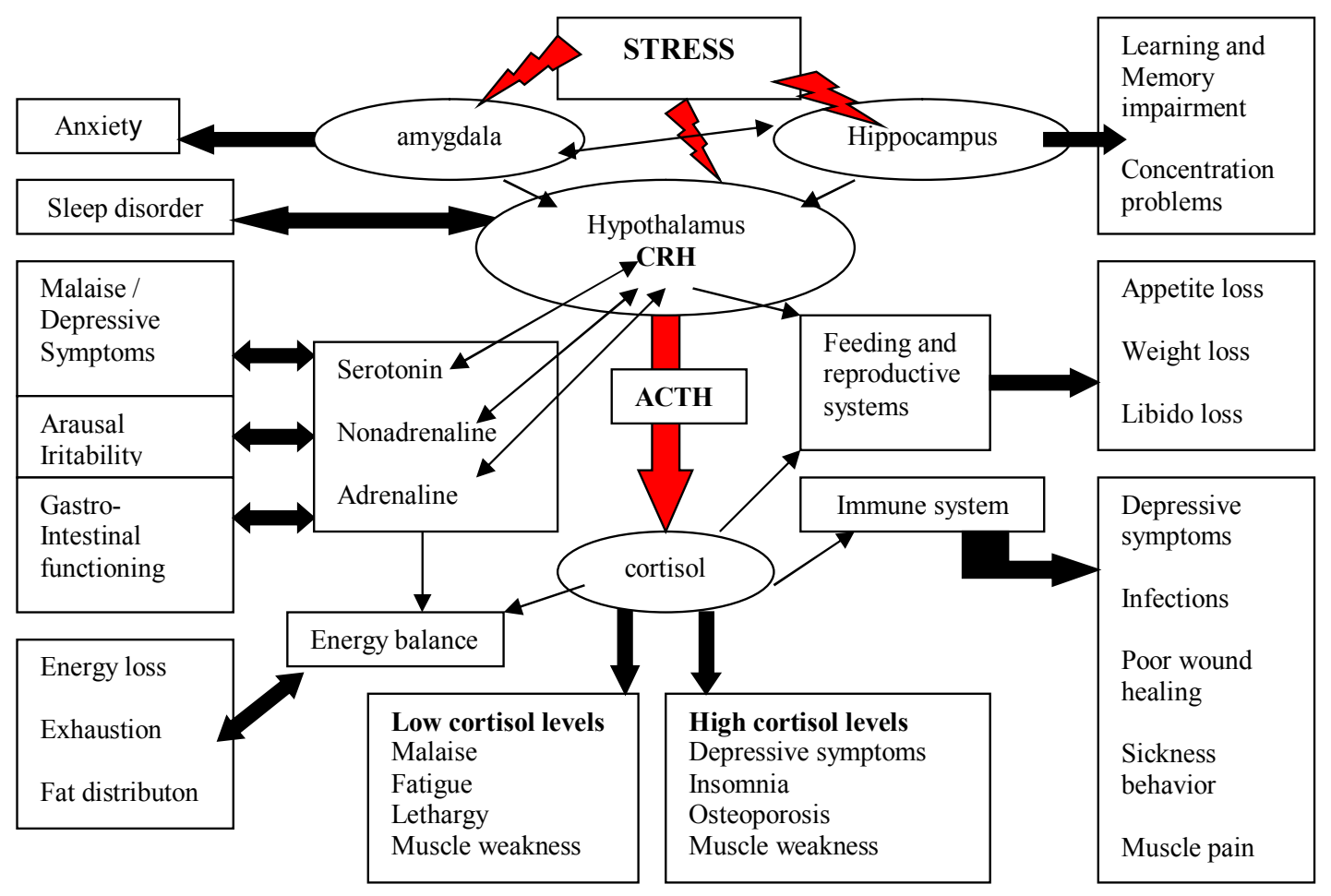

Gamabar 1 : Physiology of burnout (Mommersteeg, 2006) 
Menurut Palma (2002) orang yang mengalami kelelahan dalam memproduksi adrenal dapat disebabkan oleh ketegangan emosional dan emosi yang negatif. Sedangkan menurut (Desinta, 2011) kondisi seseorang yang mengalami kelelahan dalam memproduksi hormon adrenalin dan epinephrine, dapat memperburuk kondisi tubuh, misalnya mengalami penurunan sistem immune. Serta dampak yang ditimbulkan dari burnout akan menurunkan motivasi terhadap kerja, sinisme, timbulnya sikap negatif, frustasi, perasaan ditolak oleh lingkungan, gagal memenuhi tuntutan pekerjaan, dan self-esteem yang rendah.

Melihat kondisi tersebut sangat penting bagi individu untuk mengembalikan kondisi tubuh ke keadaan rileks agar terjadi penurunan sistem kerja saraf simpatetik. Selain itu saat stres tubuh memproduksi hormon stres, adrenalin dan epinephrine yang sangat kurang baik untuk tubuh jika dibiarkan dalam waktu lama, untuk mencegah tubuh dari kelelahan dalam memproduksi hormon tersebut maka diperlukan pencegahan.

Penelitian-penelitian mengenai intervensi untuk mengatasi telah banyak dilakukan untuk mengatasi masalah burnout, salah satunya adalah dengan pendekatan psikologis, seperti koping fokus emosi dalam menurunkan kecenderungan burnout pada perawat (Savitri, 2010), intervensi harapan untuk menurunkan burnout pada perangkat desa penyintas lahar dingin merapi (Sokang, 2012), pengaruh musik shalawat terhadap penurunan burnout karyawan (Ulfa, 2008). Salah satu cara yang dapat dilakukan untuk menurunkan burnout adalah dengan mengaktifkan sistem kerja saraf parasimpatetis dengan membiasakan tubuh untuk rileks, hal ini bisa didapat melalui tertawa. Penelitian mengenai tertawa menunjukkan efek positif terhadap kondisi fisiologis dan psikologis, seperti saat tertawa secara langsung dapat menyebabkan beberapa perubahan fisiologis pada tubuh, yang memiliki efek positif pada kesehatan, tertawa dapat menimbulkan keadaan emosional yang lebih positif, tawajuga memiliki kualitas sebagai media katarsis (Palma, 2002), serta dengan tertawa secara tidak langsung dapat menjadi strategi koping terhadap stres.

Sofro (Desinta, 2011) menjelaskan dengan tertawa dapat meningkatkan sistem kerja syaraf parasimpatis yang dapat membuat tubuh lebih rileks. Kondisi rileks dapat diperoleh setelah melakukan tawa, serta dengan tawa dapat menurunkan level stres. Penelitian Kataria (2012) menunjukkan dampak yang sangat signifikan pada karyawan yang telah melakukan intervensi tawa di tempat kerja dalam beberapa aspek self efficacy termasuk pengaturan diri, optimisme, emosi positif, meningkatkan hubungan sosial, meningkatkan moral karyawan, ketahanan, dan keyakinan akan keberhasilan diri. Menurut Mathew (2003) bahwa tawa merupakan obat yang terbaik.

Beberapa penelitian terapi tawa yang dilakukan dalam upaya menurunkan masalah psikologis diantaranya adalah terapi tawa dapat menurunkan kondisi stres dan tekanan darah pada hipertensi ringan (Desinta,2011), terapi tawa menunjukkan efek positif dalam mengurangi tingkat stres pada mahasiswa keperawatan (Kaur dan Walia, 2008), terapi tawa memberikan efek positif pada penurunan kelelahan postpartum dan stres pada wanita pasca melahirkan (Shin, Ryu, dan Song, 2011), dan terapi tawa dapat menurunkan tingkat stres kerja pada pegawai kereta api (Prasetyo dan Nurtjahjanti, 2011).

Menurut Darwin (Hasanat, 1997) sebagai orang yang pertama kali menyatakan bahwa gerakan otot zygomatic major (otot yang dapat menarik sudut bibir ke atas 
sampai tulang pipi) merupakan pusat ekspresi pengalaman emosi positif, kondisi ini sama halnya saat sedang tertawa terjadi gerakan otot zygomatic major. Menurut Muhammad (2011) tertawa dapat membangkitkan energi positif seperti setelah tertawa dapat membuat tubuh menjadi lebih rileks, pandangan mata menjadi jernih, pendengaran menjadi jernih, dan pikiran menjadi lebih optimal. Selain itu tertawa dapat menyingkirkan energienergi negatif menjadi energi positif, tertawa dapat melarutkan kesedihan, kecemasan, kemarahan, serta dengan tertawa dapat mengeluarkan hormon bahagia. Pada saat tertawa individu akan mengasup oksigen yang lebih banyak, sehingga membuat tubuh menjadi lebih rileks dan dapat menurunkan hormon adrenalin dan epinephrine. Kondisi tubuh yang demikian akan membuat tubuh terhidar dari masalah psikologis seperti burnout yang menyebabkan kelelahan emosional, fisik, maupun mental.

Berdasarkan uraian diatas diharapkan guru pendamping anak berkebutuhan khusus dapat memberikan kinerja yang terbaik dalam memberikan pelayanan serta mampu mewujudkan harapan yang sesungguhnya sebagai seorang guru yang berprofesi sebagai pengajar dapat terlaksana sesuai dengan kodratnya sebagai seorang guru dalam memberikan pelayanan, sehingga dalam penelitian ini ingin mengetahui apakah ada pengaruh terapi tawa dalam menurunkan kecenderungan burnout pada guru pendamping anak berkebutuhan khusus.

\section{Metode Penelitian}

Desain penelitian yang digunakan dalam penelitian ini termasuk ke dalam Quasi Experimental Design. Dikatakan quasi eksperimental karena pemilihan subjek tidak menggunakan random melainkan berdasarkan kriteria yang telah ditentukan oleh peneliti. Kelompok eksperimen dalam penelitian quasi eksperimen mendapatkan perlakuan,akan tetapi pemilihan kelompok eksperimen ditentukan berdasarkan kriteria peneliti sehingga tidak menggunakan random (Barker, dkk, 2002). Desain dalam penelitian ini dengan menggunakan nonrandomized pre-test post-test with control group design (Latipun, 2004).

Tabel 1 : Desain penelitian

\begin{tabular}{llllcl}
\hline & Kelompok & Pre-test & Perlakuan & $\begin{array}{c}\text { Post } \\
\text { test }\end{array}$ & $\begin{array}{c}\text { Follow- } \\
\text { up }\end{array}$ \\
\hline $\mathrm{Nr}$ & Ekperimen & $\mathrm{O} 1$ & $\mathrm{X}$ & $\mathrm{O} 2$ & $\mathrm{O} 3$ \\
$\mathrm{nR}$ & Kontrol & $\mathrm{O} 4$ & $-\mathrm{X}$ & $\mathrm{O} 5$ & $\mathrm{O} 6$ \\
\hline
\end{tabular}

Keterangan:

O1 : Skor skala kecenderungan burnout sebelum perlakuan (pretest) O2 : Skor skala kecenderungan burnout sesudah perlakuan (posttest) $\mathrm{O} 3$ :Skor skala kecenderungan burnout sesudah perlakuan (follow-up)

$\mathrm{X}$ : Perlakuan

O4 : Pretest kelompok kontrol O5 : Posttest kelompok kontrol O6 : Followup kelompok kontrol

-X : Tanpa perlakuan (perlakuan tertunda)

$\mathrm{nR}$ : Non random assignment

Subjek penelitian dipilih dengan teknik menggunakan purposive-sampling, yang artinya bahwa penentuan sampel mempertimbangkan kriteria-kriteria tertentu yang telah dibuat terhadap obyek yang sesuai dengan tujuan penelitian. Adapun kriteria sampel dalam penelitian ini adalah guru pendamping anak berkebutuhan khusus, mengalami kecenderungan burnout minimal sedang, sesuai dengan kriteria yang ditetapkan. Kriteria pemilihan ini karena kondisi kecenderungan burnout sedang merupakan kondisi yang sudah 
cukup mempengaruhi kinerja guru dalam mendampingi anak, belum pernah mengikuti terapi tawa dan memiliki kemauan dan bersedia untuk mengikuti terapi tawa.

Perlakukan yang di berikan berupa terapi tawa yang merupakan diadaptasi dari model terapi tawa (Kataria, 2004). Terapi tawa di berikan berdasarkan tahap-tahap yang terdiri dari tahap awal pemanasan yang terdiri dari pernafasan dalam dan peregangan. Tahap inti gerakan tawa dan tepuk tangan berirama. Tahap penutupan terdiri dari relaksasi pernafasan dan afirmasi positif.

Analisis data penelitian diolah dengan menggunakan metode kuantitatif dan kualitatif. Pengujian hipotesis dilakukan secara kuantitatif dengan menguji perbedaan skor kecenderungan burnout sebelum (pre-test), sesudah (post-test) pada kelompok eksperimen dan kontrol menggunakan non paramettrik tests dengan Uji Mann Whitney U-Test. Uji Mann Whitney $U$-Test digunakan untuk membedakan antara dua kelompok yaitu pada kelompok eksperimen dibandingkan dengan kelompok kontrol ( Pallant, 2005). Analisis kualitatif dilakukan terhadap data yang diperoleh dari hasil wawancara pada saat pre-test, post-test dan follow-up dan hasil observasi. Analisis kualitatif dilakukan untuk mengetahui dinamika psikologis pengaruh terapi tawa terhadap kecenderungan burnout pada guru pendamping anak berkebutuhan khusus.

\section{Hasil dan Pembahasan}

Berdasarkan hasil analisis data dengan uji Mann Whitney bahwa hipotesis dapat diterima, yaitu terdapat perbedaan yang sangat signifikan antara kelompok eksperimen dan kelompok kontrol setelah diberikan terapi tawa dengan gain score nilai $Z=-2,009$ dan taraf signifikansi $0,045(\mathrm{p}<0,05)$ sehingga dengan demikian terbukti bahwa terapi tawa efektif untuk menurunkan kecenderungan burnout pada guru pendamping anak berkebutuhan khusus.

Tabel 2. Rangkuman hasil uji Mann Whitney terhadap skor gain score antara kelompok eksperimen dan kelompok kontrol

\begin{tabular}{cc}
\hline & Gain Score \\
\hline $\mathrm{Z}$ & $-2,009$ \\
Sig & 0,045 \\
Mean & $\mathrm{KE}=3,60$ \\
Rank & $\mathrm{KK}=7,40$ \\
\hline
\end{tabular}

Berdasarkan analisis kualitatif, terlihat dari hari ke hari masing-masing subjek merasakan reaksi yang berbedabeda setelah melakukan terapi tawa. Adapun perubahan reaksi secara umum yang dirasakan subjek setelah melakukan terapi tawa merasa lebih rileks, lebih lega, dapat membantu dalam melepaskan emosi-emosi negatif, membawa hati senang saat melihat subjek yang lain tertawa, merasa bahwa kegiatan yang dilakukan menyenangkan, cukup memberikan manfaat, mengasyikkan dan seru. Selain itu subjek merasa kegiatan yang dilakukan membuat antar subjek merasa lebih akrab dan ada salah satu subjek merasakan bahwa kegiatan yang dilakukan dapat membuat dirinya merasa lebih bisa terbuka untuk mengungkapkan perasaan dibandingkan sebelumnya.

Berdasarkan hasil penelitian bahwa terapi tawa dapat menurunkan kecenderungan burnout pada guru pendamping anak berkebutuhan khusus, hal ini dapat dilihat dari penurunan skor kecenderungan burnout yang diukur menggunakan Skala Kecenderungan Burnout setelah diberikan terapi tawa yang berada pada kategori rendah. Hasil analisis data menunjukkan 
bahwa antara kelompok eksperimen dan kelompok kontrol terdapat perbedaan yang sangat signifikan setelah diberikan terapi tawa dengan nilai $\mathrm{Z}=-2,009$ dan taraf signifikansi 0,045 $(\mathrm{p}<0,05)$.

Berdasarkan hasil data kualitatif dapat digambarkan bahwa secara umum partisipan merasakan ada perubahan setelah mengikuti terapi tawa, diantaranya partisipan merasa lebih nyaman, tenang, rileks, bersemangat, dapat melepaskan emosi-emosi negatif, berpikir lebih positif, merasa bahagia, dan dapat terjalin suasana akrab antar partisipan. Penelitian ini cenderung berhasil dilakukan karena seluruh partisipan mampu melakukan latihan tawa dengan baik dan benar. Partisipan mampu merasakan dan menikmati latihan tawa yang dilakukan dari hari ke hari serta mampu merasakan setiap pengalaman fisik maupun psikis yang terjadi selama dan setelah melakukan latihan tawa, selain itu terapi tawa yang diberikan kepada partisipan secara kontinyu dan bertahap dari hari kehari memberikan manfaat yang positif, hal ini didukung oleh pendapat Prasetyo dan Nurtjahjanti (2011) bahwa terapi tawa akan lebih efektif memberikan manfaat jika diterapkan secara kontinyu.

Berdasarkan hasil evaluasi setiap pertemuan secara umum partisipan merasakan bahwa kegiatan terapi tawa yang dilakukan cukup memberikan semangat, menyenangkan, memberikan rasa nyaman, cukup bermanfaat, membuat lebih ceria, dan membuat suasana lebih cair setelah seharian fokus pada pekerjaan masing-masing. Beberapa hal yang mendukung bahwa terapi tawa baik untuk kesehatan psikologis karena disusun berdasarkan prinsip psikologis yang dapat berfungsi menurunkan beberapa gejala stres, adapun kondisi seseorang yang mengalami kecenderungan burnout akibat akumulasi dari stres yang berkepanjangan beberapa gejala yang dirasakan menyerupai gejala stres sehingga dengan diberikan terapi tawa dapat menurunkan kecenderungan burnout.

Tahapan yang dilakukan dalam terapi tawa, pertama tahap persiapan, yaitu breathing (pernafasan) yang penting untuk kehidupan, pernafasan yang sesuai dapat menurunkan gejala stres. Pada saat bernafas diafragma ikut mengambil peranan yang cukup penting untuk memisahkan antara dada dan perut. Individu dapat mengerutkan dan mengembangkan diafragma secara disadari yang umumnya dapat berjalan secara otomatis. Saat mengalami kecendeurngan burnout yang diawali dengan gejala stres mengakibatkan proses bernafas menjadi cepat dan tidak beraturan, untuk melepaskan kondisi ini dapat dilakukan dengan menghirup udara sebanyak-banyaknya dan menghembuskan secara perlahan. Di dalam tawa pernafasan ini disebut pranayama yaitu teknik-teknik pernafasan yang pelan dan berirama yang membantu terciptanya relaksasi fisik, mental dan memberikan efek menenangkan pikiran serta memberikan lebih banyak oksigen untuk jaringan tubuh sehingga meningkatkan kapasitas untuk tertawa (Kataria, 2004). Hal ini dirasakan oleh beberapa partisipan bahwa dengan menarik nafas dalam saat merasakan kondisi kurang nyaman dapat membantu menenangkan pikiran, dan memberikan rasa rileks serta dapat membantu kapasitas partisipan dalam tertawa yang terlihat dari hasil observasi seluruh partisipan dapat melakukan gerakan tawa dengan baik dan benar.

Tahap persiapan yang ke dua physical relaxation merupakan hal terpenting dari beberapa gerakan tawa yoga, yaitu pada gerakan tepuk tangan berirama dan teknikteknik tawa yoga. Gerakan ini merupakan latihan pemanasan yang merangsang titiktitik acupressure di telapak tangan serta 
membantu menciptakan rasa nyaman dan meningkatkan energi, serta latihan peregangan pada tahap persiapan tawa juga merupakan salah satu bentuk relaksasi fisik yang dapat memberikan penyegaran fisik dan stamina tubuh, hal ini terlihat pada tahap persiapan yang diikuti tepuk tangan berirama dan menyuarakan ho ho ha ha ha partisipan terlihat bersemangat dan cukup antusias untuk mengikuti dan melakukan gerakan tawa, sehingga suasana yang terlihat cukup hangat, akrab dan antar partisipan dapat bekerjasama dengan baik dalam melakukan tawa.

Tahapan inti sesi tawa yang merupakan prinsip dasar psikologis adalah mengembangkan kemampuan komunikasi tawa untuk menyatukan orang dan memperbaiki hubungan interpersonal. Kemudian mencari social support yang merupakan salah satu teknik melakukan coping terhadap stres. Seluruh tawa yang dilakukan melibatkan interaksi pada orang lain untuk mencari social support adalah tawa sapaan, tawa penghargaan, tawa milk shake, tawa hening tanpa suara, tawa sup panas, tawa mengayun, tawa singa, tawa ponsel, tawa memaafkan dan tawa dari hati ke hati. Berdasarkan hasil observasi yang didapat pada tahap inti seluruh partisipan secara umum mampu melakukan tawa dengan baik, mampu terlibat satu sama lain dalam melakukan tawa walaupun terkadang beberapa partisipan diawal tawa masih terlihat kurang nyaman, akan tetapi hal ini tidak mempengaruhi partisipan untuk melakukan tawa dari awal sampai akhir, secara umum antar partisipan dapat terjalin suasana yang akrab.

Tahap penutup mental relaxation melakukan relaksasi pernafasan kemudian meneriakkan afirmasi positif. Gerakan teknik penutupan berdasarkan prinsip dasar Hasya yoga dimana mental relaxation dilakukan untuk menyelaraskan tubuh, pikiran, dan jiwa sehingga dapat menekan stres (Kataria, 2004), pada tahap penutupan partisipan terlihat bersemangat saat meneriakkan afirmasi positif.

Beberapa hasil penelitian yang didapat menguatkan penelitian yang dilakukan oleh (1) Kaur dan Walia (2008) bahwa terapi tawa dapat mengurangi tingkat stres, (2) penelitian Desinta (2011) bahwa terapi tawa dapat menurunkan tingkat stres pada penderita hipertensi. Kedua penelitian tersebut ada kesamaan dengan penelitian yang telah dilakukan bahwa orang yang mengalami kecenderungan burnout akibat dari akumulasi stres yang berkepanjangan dan beberapa gejala yang dirasakan menyerupai gejala stres dengan diberikan terapi tawa dapat menurunkan kecenderungan burnout.

Butler (2005) menjelaskan bahwa tertawa merupakan obat paling baik untuk kesehatan fisik dan psikis, hal ini terlihat dari penurunan skor kecenderungan burnout pada kelompok eksperimen setelah diberikan terapi tawa berada pada kategori rendah yang sebelumnya berada pada kategori sedang, selain itu partisipan merasa nyaman setelah melakukan tawa, dapat melepaskan emosi-emosi negatif, mampu berpikir lebih positif dan merasa bahagia.

Hasil penelitian yang didapat juga mendukung pendapat Kataria (2004) bahwa terapi tawa yang dilakukan di tempat kerja akan meningkatkan hubungan interpersonal, meningkatkan rasa saling percaya diri, meningkatkan cara pandang yang lebih positif, dan meningkatkan iklim kerja serta kinerja pada karyawan hal ini kaitannya dengan burnout yaitu disaat individu mengalami burnout memiliki konsep diri yang rendah, memiliki cara pandang yang negatif dengan diberikan terapi tawa dapat memperbaiki cara pandang yang lebih positif. Menurut Muhammad (2011) saat 
melakukan tawa wajah, perut dan pernafasan akan bergerak serentak, saat itu akan terjadi peregangan otot, peningkatan denyut nadi, dan penyebaran oksigen ke semua jaringan dalam tubuh, aktivitas inilah yang akan melancarkan darah pada seluruh tubuh. Pada kondisi tertawa beberapa hormon baik akan terpacu seperti hormon bahagia (dopamine dan endorphin), serta dengan tertawa dapat membangkitkan semangat dan menjernihkan pikiran, penjelasan tersebut didukung dengan hasil penelitian yang didapat bahwa partisipan merasakan bahagia setelah melakukan tawa, lebih bersemangat dan berpikir lebih positif.

Muhammad (2011) juga menjelaskan bahwa tertawa banyak sekali memberikan manfaat pada psikis maupun sosial, dimana saat tertawa dapat berpengaruh terhadap keseimbangan emosi, terutama dalam hubungan dengan orang lain dapat menjadi penjalin persahabatan apabila diberikan pada tempat semestinya. Penjelasan Muhammad didukung dengan hasil penelitian yang telah dilakukan bahwa semua partisipan merasakan suasana yang lebih akrab selama melakukan terapi tawa bersamasama. Tawa merupakan pendekatan holistik yang mempunyai dampak positif bagi kesehatan individu, seperti meningkatkan konsentrasi, meningkatkan rasa percaya diri, memperbaiki hubungan antar pribadi, dan juga merupakan meditasi yang sederhana, penjelasan tersebut ada kaitannya dengan hasil penelitian yang didapat bahwa partisipan merasakan suasana yang akrab antar partisipan, berpikir lebih positif, dapat melepaskan emosi-emosi negatif dan merasakan rileks.

Hasil penelitian ini juga mendukung penelitian Kataria (2012) yang menunjukkan ada pengaruh sangat signifikan pada karyawan yang telah melakukan intervensi tawa di tempat kerja dalam beberapa aspek self efficacy termasuk pengaturan diri, optimisme, emosi positif, meningkatkan hubungan sosial, meningkatkan moral karyawan, ketahanan, dan keyakinan akan keberhasilan diri. Hubungannya dengan penelitian yang telah dilakukan bahwa partisipan merasakan emosi yang positif dan dapat meningkatkan keakraban antar partisipan.

Penelitian yang telah dilakukan juga mendukung penjelasan Tarigan (2009) yang menjelaskan bahwa tertawa dapat membentuk pola pikir positif sehingga seseorang akan berpikir dengan cara yang lebih positif. Selain itu pendapat Mathofani dan Wahyuni (2011) bahwa tertawa dapat merilekskan otot-otot yang tegang, pendapat ini mendukung hasil penelitian yang didapat bahwa partisipan dalam penelitian ini merasakan rileks setelah melakukan tawa. Menurut Septianto (2011), tertawa merupakan salah satu bagian dari ekspresi emosi manusia dan terbukti dapat menurunkan kadar emosi manusia. Tertawa yang dilakukan secara teratur dan tidak berlebihan dapat berpengaruh positif bagi kesehatan. Pendapat tersebut mendukung hasil penelitian yang diperoleh bahwa partisipan dapat melepaskan emosiemosi negatif setelah tertawa, dimana terdapat penurunan kadar emosi dari emosi negatif menjadi emosi positif. Sedangkan menurut Palma (2002) selain tawa dapat menimbulkan keadaan emosional yang lebih positif, tawa juga memiliki kualitas sebagai media katarsis yang memberikan efek positif terhadap kesehatan.

Hasil penelitian yang dilakukan Mathofani dan Wahyuni (2011) menunjukkan adanya pengaruh terapi tertawa terhadap kecemasan mahasiswa program ekstensi dalam menghadapi skripsi di Fakultas Keperawatan USU Medan, selain itu Mathofani dan Wahyuni juga mengatakan 
bahwa terapi tawa direkomendasikan sebagai salah satu alternatif untuk mengurangi kejenuhan dan kecemasan. Hasil penelitian tersebut mendukung hasil penelitian yang diperoleh bahwa terapi tawa dapat menurunkan kejenuhan pada guru pendamping anak berkebutuhan khusus. Selain kelebihan yang didapat dari manfaat terapi tawa yang telah dilakukan penelitian ini masih terdapat kelemahan, yaitu mengenai waktu pelaksanaan setelah kegiatan belajar mengajar yang membuat beberapa partisipan terlihat mengantuk diawal pertemuan.

\section{Simpulan}

Berdasarkan hasil penelitian dapat disimpulkan bahwa terapi tawa dapat menurunkan kecenderungan burnout pada guru pendamping anak berkebutuhan khusus, hal ini diindikasikan dengan menurunnya skor kecenderungan burnout pada kelompok eksperimen yang sebelum diberikan terapi tawa berada pada kategori sedang dan setelah diberikan terapi tawa berada pada kategori rendah. Terlihat dari hari ke hari masing-masing partisipan merasakan reaksi yang berbeda-beda setelah melakukan terapi tawa. Beberapa perubahan reaksi yang dirasakan partisipan secara umum setelah melakukan tawa merasa lebih rileks, lebih lega, dapat membantu dalam melepaskan emosi-emosi negatif, membawa hati senang saat melihat partisipan yang lain tertawa, kegiatan yang dilakukan menyenangkan, cukup memberikan manfaat, mengasyikkan dan seru. Peneliti selanjutnya diharapkan untuk mengkhususkan karakteristik yang sama pada anak yang didampingi oleh guru pendamping anak berkebutuhan khusus. diharapkan dapat melakukan terapi tawa padawaktu pagi hari, karenajika mengawali hari dengan tawa dapat menciptakan suasana hati yang nyaman sepanjang hari.

\section{Daftar Pustaka}

Anna, L., K. (2012). Burnout, ketika hidup tanpa variasi. http://health.kompas. com . Senin 10 Desember 2012, 12 $: 07$.

Alimin, Zaenal (2004) Reorientasi Pemahaman Konsep Pendidikan Khusus Pendidikan Kebutuhan Khusus dan Implikasinya terhadap Layanan Pendidikan. Jurnal Asesmen dan Intervensi Anak Berkebutuhan Khusus. Vol.3 No 1 (52-63).

Ayu, A. (2009). Terapi Tertawa untuk Hidup Lebih Sehat, Bahagia dan Ceria. Yogyakarta: Pustaka Larasati.

Azwar, S. (2000). Penyusunan Skala Psikologi. Yogyakarta: Pustaka Pelajar.

Azwar, S. (2005). Penyusunan Skala Psikologi. Yogyakarta: Pustaka Pelajar.

Barker, C., Pistrang, N., \& Elliot, R., (2002). Research Methods in Clinical Psychology. Second Edition. England: John Wiley \& Sons, Ltd.

Bennet, M.P. Zeller, J.M. \& McCann, J. (2003). The Effect of Mirthfull Laugther on Stress and Natural Killer Cell Activity. Alternative Therapies. 9 (2), 28-43.

Beckman, H., Regier, N., \& Young, J. (2007). Effect of Workplace Laughter Groups on Personal Efficacy Beliefs. The Journal of Primary Prevention. 28, 167-182.

Butler, B. (2005). Laughter The Best Medicine?. Oregon Institute of Marine 
University of Oregon Biology. Spring. Vol 11 No 1.

Carolina. (2006). Pendidikan Anak Luar Biasa. Jakarta : PT. Rafika Aditama.

Carrel, R.M., Jennings, F.D., \& Heavrin, C. (1997). Fundamentals of Organizational Behavior. PrenticeHall, inc. United States of America.

Cho, E., A \& Oh, H., E. (2011). Effects of laughter therapy on depression, quality of life, resilience and immune responses in breast cancer survivors. Journal of Korean Academic of Nursing. 41 (3) : 285-293. www.researchgate.net/ publication/51535599_Effects_of_ laughter_therapy_on_depression_ quality_of_life_resilience_and_ immune_responses_in_breast cancer_survivors. (diunduh $1 \overline{7}$ Desember 2012).

Damayanti, A. (2008). Hubungan Antara Burnout Dengan Kepuasan Kerja Pada Anggota Kepolisian Poltabes Yogyakarta. Skripsi (tidak diterbitkan) Universitas Ahmad Dahlan.

Demirel, Y., Toktamis, A., Ozdemir, D., \& Sezer, E. (2005). Burnout Among High School Teachers in Turkey. Middle East Journal of Family Medicine. Vol 3 (3).

Desinta, S. (2011). Terapi Tawa Untuk Menurunkan Stres Pada Penderita Hipertensi. Tesis (tidak diterbitkan). Universitas Gajah Mada Yogyakarta.

Dorman, J. (2003). Testing A Model For Teacher Burnout. Australian Journal of Educational \& Developmental Psychology. Vol 3, Hal 35-47.

Erdman, L. (2009). Laugther Therapy For Patients With Cancer. Journal of
Psychosocial Oncology. $11:$ 4, 55-67.

Fathoni, I. D. (2003). Pengaruh Kecerdasan Emosi Terhadap Kecenderungan Burnout Perawat di RSUD Dr. Moewardi Surakarta. Tesis. (tidak diterbitkan). Universitas Gajah Mada Yogyakarta.

Freudenberger, H.J., \& Richelson, G. (2003). Burnout: How to Beat The High Cost of Succes. New York: Bantam Book.

Hasanat, N., U. (1997). Anda Sedang Bersedih? Cobalah Tersenyum Atau Tertawa. Suatu Bukti Dari Facial Feedback Hypothesis. Buletin Psikologi. Tahun V. No. 2

Kaur, L. \& Walia, I. (2008). Effect Of Laughter Therapy On Level Of Stress: A Study Among Nursing Students. Nursing And Midwifery Research Journal, Vol-4, No. 1.

Kataria, M. (2012). An Update On Laughter yoga. www.Vsplugins.com//LaughterYoga-Dr-Gita-S-N .

Kataria, M. (2004). Laugh for No Reason (Terapi Tawa). Penerjemah: PT Gramedia Pustaka Utama Anggota IKAPI. Jakarta: PT Gramedia Pustaka Utama.

Ko, H., J \& Youn, C., H. (2011). Effect of laughter therapy on depression Jepang Geriatrics Society.

Kreitner, R. \& Kinicki, A. (2005). Perilaku Organisasi. Organizational Behavior. Jakarta: Salemba Empat.

Latipun. (2004). Psikologi Eksperimen. Malang : UMM Press. Edisi 2.

Mahavidyalaya, A., A. (2012). Laughter Therapy (World Laughter DayFirst Sunday Of Mei). Journal 
Of Pharmaceutical and Scientific Innovation. JPSI 1 (3), May-June, 23-24.

Maslach, C., \& Leiter, M.P. (2008). Early predictor of job burnout and engagement. Journal of Applied Psychology, Vol.93, No. 3, 498-512.

Mathew, F., M.(2003). Laughter Is The Best Medicine : The Value Of Humor In Current Nursing Practice. Nursing Journal Of India. Vol.7. 252-255.

Mathofani, W. S. \& Wahyuni, S. E. (2011). Terapi Tertawa dan Kecemasan Mahasiswa Program Ekstensi Dalam Menghadapi Skripsi Di Fakultas Keperawatan USU. Jurnal Keperawatan Usu. (diunduh tanggal 29 januari 2014).

Mommersteeg, P. M. C. (2006). The psychophysiology of burnout. Netherlands. Chapter 1. Halaman 15.

Muhammad, A. (2011). Tertawalah Biar Sehat !. Yogyakarta: Diva Press.

Nasution, S. (2010). Didaktik Asas-Asas Mengajar. Edisi Kedua. Jakarta : PT Bumi Aksara.

Palma, J.R.D (2002). Laughter as medicine. www.hemodialysis-inc.com/readings/ laughter.pdf.

Pallant, J. (2005). SPSS Survival Manual : A Step By Step Guide To Data Analysis Using SPSS. Australia : Allen \& Unwin.

Pamangsah, A. (2008). Penanggulangan Stres Kerja. Yogyakarta: STIE.

Prasetyo, A. R \& Nurtjahjanti, H. (2011). Pengaruh Penerapan Terapi Tawa Terhadap Penurunan Tingkat Stres Kerja Pada Pegawai Kereta Api.
Jurnal Psikologi Undip. Vol. 10, No.2.

Rahman, U. (2007). Mengenal Burnout Pada Guru. Lentera Pendidikan. Edisi X. No.2. Halaman 216-227.

Rosyid, H. F \& Farhati, F. (1996) Karakteristik Pekerjaan, Dukungan Sosial dan Tingkat Burnout Pada Non Human Service Corporation. Jurnal Psikologi, 1: 1-12.

Savitri, I., G., A., Y. (2010). Pengaruh Koping Fokus Emosi Terhadap Kecenderungan Burnout pada Perawat. Tesis (tidak diterbitkan). Universitas Gajah Mada Yogyakarta.

Safaria, T. \& Saputra, N. E. (2009). Manajemen Emosi Sebuah Panduan Cerdas Bagaimana Mengelola Emosi Positif Dalam Hidup Anda. Jakarta: Bumi Aksara.

Schaufeli, W., B., Martinez, I., M., Pinto, A., M., Salanova, M., \& Bakker, A., B. (2002) Burnout And Engagement In University Students : a Cross-National Study. Journal of Cross-Cultural Psychology, Vol 33 No.5, 464-481.

Septianto, T. (2011). Pengaruh Positif Tertawa Untuk Kesehatan. Diunduh pada tanggal 3 Januari 2014 dari http:// suaramerdeka.com/v1 /index.php/ read/sehat/2011/06/19/605/PengaruhPositif-Tertawa-untuk-Kesehatan.

Shahidi, M., Mojtahed, A \& Honari, H. (2010). Laughter Yoga Versus Group Exercise Program In Elderly Depressed Women: A Randomized Controlled Trial. International Journal Of Geriatric Psychiatry. (editor). Chichester: John Wiley dan Sons, Ltd.

Shin, H. S., Ryu, K. H., \& Song, Y. A. 
(2011). Effect Of Laughter Therapy On Postpartum Fatigue And Stress Responses Of Postpartum Women. 41 (3):294-301. Journal Of Korea Academic Of Nusing. $\mathrm{w}$ w w.re s e a r c h g a t e.net/ publication/51535600_Effects_of_ laughter_therapy_on_postpartum_ and stress responses of postpartum. (diakses 17 Desember 2012).

Simamora, H. (1995). Manajemen Sumber Daya Manusia. Yogyakarta: STIE.

Sokang, Y., A. (2012). Intervenís Harapan Terhadap Burnout pada Perangkat Desa Penyintas Lahar Dingin Merapi. Tesis (tidak diterbitkan). Universitas Gajah Mada Yogyakarta.

Sujarweni, W. (2008). Belajar Mudah SPSS untuk Penelitian Skripsi, Tesis, Disertasi dan Umum. Yogyakarta : Global Media Informasi.

Sukmaninggrum, E. (2005). Secondary Traumatic Stress, Vicarious Trauma, Dan Burnout Pada Pendamping Yang Menangani Kekerasan Anak Dan Perempuan. Jurnal Psikologi. Vol. 15. No. 1.

Sukamto, M.E., Setiasih., Setiawan, J. L. (1998). Hubungan Antara Kebiasaan Proaktivitas (the habit of proactivity) dan Masa Kerja Dengan Gejala Burnout Pada Guru Sekolah Dasar.
Indonesian Psychological Journal. Anima. Vol XIII. No. 52. Edisi JuliSeptember. 354-373.

Sutjipto. (2001). Apakah anda mengalami kelelahan. Makalah. Badan penelitian dan pengembangan departemen pendidikan nasional.

Tarigan, I. (2009). Sehat Dengan Terapi Tertawa. Diakses pada tanggal 3 Januari 2014 dari http://www.mediaindonesia. com /mediahidupsehat /index.php/ $\mathrm{read} / 2009 / 06 / 25 / 1325 / 13 /$ Sehatdengan-Terapi-Tertawa.

Tsigilis, N. (2011). Burnout Among Physical Education Teachers in Primary and Secondary Schools. International Journal Of Humanities and Social Science. Vol. 1 No. 7 : 53-58.

Ubaydillah, A., N. (2008) Menangani Masalah Burnout di Tempat Kerja. Kategori Organisasi Industri. Jakarta, 21 Februari. http://www.e-psikologi. com (Diakses tanggal 23 November 2012).

Ulfa, M. (2008). Pengaruh Musik Shalawat Terhadap Burnout Karyawan. Skripsi. ( tidak diterbitkan). Universitas Islam Negeri Malang.

Undang-Undang Guru dan Dosen. (2009). Yogyakarta : Pustaka Pelajar. 